\title{
Biochemical attributes and establishment of tree seedlings in soil after Urochloa decumbens cultivation in soil with deposition of iron mining residues
}

\author{
Alexandre Carvalho Ribeiro Junior ${ }^{1 \mathrm{iD}}$, Aline Oliveira Silva ${ }^{1 \mathrm{iD}}$, Éder Rodrigues Batista $^{1 \mathrm{iD}}$, Filipe Sales Naves ${ }^{1 \mathrm{iD}}$, \\ Flávio Araújo Pinto ${ }^{1 \mathrm{iD}}$, Jessé Valentim dos Santos ${ }^{\mathrm{iD}}$, Marisângela Viana Barbosa ${ }^{1 \mathrm{iD}}$, \\ Ingrid Fernanda Santana Alvarenga ${ }^{1 \mathrm{iD}}$, Marco Aurélio Carbone Carneiro ${ }^{1 * \mathrm{iD}}$ \\ ${ }^{1}$ Federal University of Lavras, Lavras, Minas Gerais, Brazil
}

\section{SILVICULTURE}

\begin{abstract}
Background: The recovery of areas impacted by mining activities is a major challenge and requires knowledge of how the biological and biochemical processes of the soil as well as the establishment of plant species are affected by mining residue. In this work, the influence of deposition of iron mining mud and tailings on soil biochemical attributes and the initial development of tree seedlings was studied in a simulated event in the greenhouse. Pots $(n=27)$ with natural soil $(2.0 \mathrm{~kg})$ received deposition $(280 \mathrm{~mL})$ of iron mining mud or tailings and by three-month was cultivated with Urochloa decumbens. At the end of this period, part of the pots was sampled and the soil biochemical activities were evaluated. Then tree seedlings (Schinus terebinthifolius and Eremanthus incanus) were planted and cultivated for a year, when then shoot (SDW) and roots (RDW) dry weight were evaluated.
\end{abstract}

Results: Deposition of iron mining mud and tailings did not affect microbial biomass carbon or basal soil respiration, however both conditions reduced $(p<0.05) \beta$-glucosidase activities by up to $30 \%$, and the easy extractable glomalin by about 19\%. In addition, the mud deposition reduced $(p<0.05)$ the SDW and RDW of S. terebinthifolius by about $21 \%$ and $24 \%$, respectively. Nevertheless, Uruchloa decumbens and Eremanthus incanus had no variation in dry weight production between treatments, so they have good ability to grow settle in soil affected by mining residue.

Conclusion: This study shows that the sequential planting of $U$. decumbens and $E$. incanus can be an alternative for use in environments with deposition of iron mining tailings.

Keywords: Degraded Areas, Soil Bioindicators, Revegetation, Dam collapse, Enzymatic activity.

\section{HIGHLIGHTS}

Iron mining residues (mud and tailings) reduced $\beta$-glucosidase activity and glomalin levels.

$U$. decumbens and $E$. incanus developed well in the presence of tailings or iron mining mud.

S. terebinthifolius had reductions in SDW and RDW when it was grown in the presence of iron mining mud.

RIBEIRO JUNIOR, A. C. R.; SILVA, A. O.; BATISTA, E. R.; NAVES, F. S.; PINTO, F. A.; SANTOS, J. V.; BARBOSA, M. V.; ALVARENGA, I. F. S; CARNEIRO, M. A. C. Biochemical attributes and establishment of tree seedlings in soil after Urochloa decumbens cultivation in soil with deposition of iron mining residues. CERNE, v. 27, e-102623, doi: 10.1590/01047760202127012623 


\section{INTRODUCTION}

The collapse of the Fundão dam in Mariana-Minas Gerais spilled 35-45 million $\mathrm{m}^{3}$ of iron mining residues over approximately $800 \mathrm{~km}$ in the Doce River Basin. Consequently, $\sim 1500$ hectares of riparian forests and agricultural areas were impacted by deposition or displacement of the tailings mud. The most impacted section corresponds to the first 80 km of the Basin, on the banks of the Gualaxo do Norte River, which had partial or total changes in its physical, chemical, and biological soil properties (Davila et al., 2020; Segura et al., 2016; Garcia et al., 2017; Hatje et al., 2017; Pires et al., 2017; Zago et al., 2019; Batista et al., 2020).

The rehabilitation of extensive areas impacted by spills of tailings resulting from dam collapses, such as occurred at the Fundão dam (Mariana) and Córrego do Feijão (Brumadinho), in the State of Minas Gerais - Brazil, is a great challenge. This process requires the recomposition of landscapes and the restoration of ecosystems at large scale levels. For this, the use of grasses, characterized by fast growth and good shoot production, such as those of the Urochloa genus, has shown positive results in the initial stages of the rehabilitation of environments related to mining activities (Stumpf et al., 2014; Santos et al, 2016; Pedroso et al., 2018). In addition to grasses, the use of native tree species capable of adapting to the new limiting soil conditions is essential, and some characteristics presented by tree species can be determinant for the success or failure of rehabilitation, such as: being resistant to pests and diseases, ease in acquiring propagules, adaptability, high growth rate, efficiency in absorption and use of nutrients, and tolerance to heavy metals (Accioly et al., 2000, Araújo et al., 2018). Moreover, it has been reported the benefits of the associated soil microbiota with plants to achieve success in revegetation processes (Carneiro et al., 2008; Herzberger et al., 2014; Franchi et al., 2016; Santos et al., 2016; Rangel et al., 2017; Pedroso et al., 2018). Soil microorganisms play an essential role in the availability of nutrients for plants (Van der Heijden et al., 2008; Morgan and Connolly, 2013; Tak et al., 2013; Lenart-Boroń and Boroń, 2014; Santoyo et al., 2016; Jacoby et al., 2017), besides participating in the immobilization, chemical transformation, and detoxification of chemical elements potentially toxic to plants (Tak et al., 2013; LenartBoroń and Boroń, 2014; Ma et al., 2015; Dzionek et al., 2016). Soil microorganisms indirectly also favor the establishment of plants in the soil by acting on the stabilization of soil aggregates, for example by the physical effects of fungal hyphae, as well as by the production of cementing agents such as glomalin (Wright and Upadhyaya, 1998; Rillig et al., 2004; Pedroso et al., 2018; Lehmann et al., 2017; Barbosa et al., 2019) or due to the release of biopolymers (exopolysaccharides) synthesized by certain bacterial groups (Deng et al., 2015; Lehmann et al., 2017; Costa et al., 2018). All these mechanisms depend heavily on biochemical reactions mediated by enzymes, which are part of the carbon, nitrogen, phosphorus, and sulfur cycle through the processes of decomposition and mineralization (Hojati and Nourbakhsh, 2006; Bowles et al., 2014).

The success of revegetation programs in impacted areas, therefore, will depend on the presence of an active soil microbiota associated with plants established on substrates with physical and chemical impediments. In this context, knowing how the deposition of iron mining mud and tailings affects the microbial activity and the establishment of plants may favor decision making aimed at accelerating the process of rehabilitation of areas impacted by iron mining.

Therefore, this study aimed to evaluate the impact of iron mining mud and tailings deposition on soil microbial activity and on the establishment of $U$. decumbens and tree species with potential for use in rehabilitation processes. We hypothesized that the deposition of iron mining mud or tailings on the soil reduces the soil microbial activity and consequently affects the development of pre-existing vegetation ( $U$. decumbens), as well as the initial growth of native plants used in the revegetation process.

\section{MATERIAL AND METHODS}

The study was conducted in a greenhouse at the Department of Soil Sciences at the Federal University of Lavras, in two stages (Fig 1). I - simulation of iron mining mud and tailings deposition on a non-impacted soil, cultivated with Urochloa decumbens. This species of grass was chosen for this study because it has the ability to grow in soils with low fertility and physical limitations and produce abundant vegetation cover in a short time. Three months later, the effects of this deposition on different soil biological attributes and development of $U$. decumbens were evaluated. II - began with the planting of seedlings of two tree species and, after one year, evaluation of the development of these native tree species in the affected soils. The experiment was conducted in a completely randomized design with 27 replications. Each pots received $2.0 \mathrm{~kg}$ of Dystrophic Red Latosol (non-impacted soil by tailings or mining mud, collected in a native forest at the Federal University of Lavras, 21013'42" S, 44058'02" W). Chemical characteristics of the soil are shown in Tab. 1. At the time of sowing, each pot received 15 seeds of $U$. decumbens and $50 \mathrm{ml}$ of nutrient solution ( $\left.\mathrm{g} \cdot \mathrm{L}^{-1}\right) 26.42 \mathrm{~g}$ $\mathrm{NH}_{4} \mathrm{H}_{3} \mathrm{PO}_{4^{\prime}} 3.5 \mathrm{~g} \mathrm{~K}_{2} \mathrm{SO}_{4^{\prime}} 0.20 \mathrm{~g} \mathrm{H}_{3} \mathrm{BO}_{3^{\prime}} 0.54 \mathrm{~g} \mathrm{MnSO}_{4} \mathrm{H}_{2} \mathrm{O}$, $0.14 \mathrm{~g} \mathrm{CuSO}_{4} 5 \mathrm{H}_{2} 0,0.47 \mathrm{~g} \mathrm{ZnSO}_{4} 7 \mathrm{H}_{2} \mathrm{O}, 0.37 \mathrm{~g} \mathrm{KCl}$, and $26.19 \mathrm{~g} \mathrm{NH}_{4} \mathrm{H}_{2} \mathrm{PO}_{4} .26$ and 37 days after sowing (DAS), cover fertilization was carried out with $\mathrm{N}$ and $\mathrm{K}$ in the doses of $0.189 \mathrm{~g}$ and $0.197 \mathrm{~g}$ of $\mathrm{K}$ in both seasons. The iron mining mud and tailings were provided by the company Samarco S/A. The mud was collected from a mining dam $\left(20^{\circ} 12^{\prime} 58^{\prime \prime} \mathrm{S}, 43^{\circ} 28^{\prime} 20^{\prime \prime} \mathrm{O}\right)$. The tailings were obtained from a stretch affected by the mining dam burst, one year after the accident. The stretch affected is located on the banks of the Gualaxo do Norte river (Pedras District, municipality

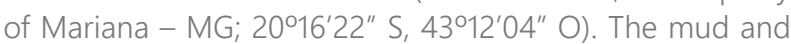
the tailings presented silt and loam sandy. Compositional analysis of some potentially toxic elements in the tailing and mud, performed using portable X-ray fluorescence (XRF), are shown in Tab. 2.

\section{First stage - Mud and tailings deposition and impacts on plant development and soil biochemical attributes.}

To simulate the impact of iron mining mud and tailing deposition on the soil, the following treatments 
Tab. 1 Chemical characteristics of iron mining mud and tailings and of a Dystrophic Red Latosol used in the experiment.

\begin{tabular}{|c|c|c|c|c|c|c|c|c|c|c|c|c|c|}
\hline \multirow{2}{*}{ Treatments } & $\mathrm{pH}$ & $P$ & K & $\mathrm{Ca}$ & $\mathrm{Mg}$ & $\mathrm{Zn}$ & $\mathrm{Fe}$ & $\mathrm{Mn}$ & $\mathrm{Cu}$ & MO & Clay & Silt & Sand \\
\hline & $\left(\mathrm{H}_{2} \mathrm{O}\right)$ & $\mathrm{mg} \cdot \mathrm{dm}^{-3}$ & ------- & $\mathrm{cmol} \cdot \mathrm{dm}^{-3}$ & $-----\cdot$ & $---\cdot$ & $-\cdots m$ & $g \cdot \mathrm{dm}^{-3}--$ & ------- & $\mathrm{g} \cdot \mathrm{kg}^{-1}$ & & & \\
\hline Mud & 8.7 & 17.46 & 0.04 & 2.24 & 0.1 & 1.17 & 199.85 & 321.67 & 0.80 & 3.30 & 4.00 & 95.00 & 1.00 \\
\hline Tailing & 8.4 & 10.24 & 0.19 & 1.21 & 0.1 & 1.26 & 221.08 & 168.41 & 0.95 & 7.00 & 8.00 & 36.60 & 55.40 \\
\hline Not-impacted soil & 5.8 & 0.28 & 0.04 & 0.10 & 0.1 & 0.90 & 19.00 & 5.60 & 1.00 & 6.50 & 68.00 & 14.00 & 18.00 \\
\hline
\end{tabular}

Tab. 2 Compositional analysis of elements of iron mining mud and tailings performed using portable $X$-ray fluorescence (XRF).

\begin{tabular}{ccc}
\hline Elements $\left(\mathrm{mg}^{\mathrm{kg}} \mathrm{f}^{-1}\right)$ & Mud & Tailing \\
\hline $\mathrm{As}$ & $<\mathrm{DL}$ & $<\mathrm{DL}$ \\
\hline $\mathrm{Cd}$ & $<\mathrm{DL}$ & $<\mathrm{DL}$ \\
$\mathrm{Cr}$ & 350.00 & 235.00 \\
$\mathrm{Cu}$ & 20.00 & 28.00 \\
$\mathrm{Fe}$ & 43.557 .00 & 178050.00 \\
$\mathrm{Hg}$ & $<\mathrm{DL}$ & $<\mathrm{DL}$ \\
$\mathrm{Mn}$ & 2090.00 & 1008.00 \\
$\mathrm{Ni}$ & 0.00 & 6.20 \\
$\mathrm{~Pb}$ & 570.00 & 52.7 \\
$\mathrm{Si}$ & 109309.00 & 1811285.00 \\
$\mathrm{Zn}$ & 10.00 & 17.2 \\
\hline
\end{tabular}

$<\mathrm{DL}$ - Values below the detection limit

were established one month after planting $U$. decumbens. nine pots received $280 \mathrm{~mL}$ of mining mud or tailing. For comparison, nine other pots had no material deposition (control treatment, not-impacted soil) (Fig. 1).

After three months, measurements of gas exchange were made in leaves of $U$. decumbens. The measurements were carried out in the period between 9 - 11 am and recorded using an infrared gas analyzer (IRGA) model - LiCor - 6400XT). LED camera of equipment was programmed to Photosynthetic photon flux density (PPFD) (DFFFA) of $600 \mu \mathrm{mol} \mathrm{m} \mathrm{m}^{-2} \cdot \mathrm{s}^{-1}$. The liquid photosynthesis $\left(\mathrm{A}-\mu \mathrm{mol} \mathrm{CO}_{2}\right.$ $\left.\mathrm{m}^{-2} \cdot \mathrm{s}^{-1}\right)$, stomatal conductance (gs - $\mathrm{mol} \mathrm{H} \mathrm{H}_{2} \mathrm{~m}^{-2} \cdot \mathrm{s}^{-1}$ ) and

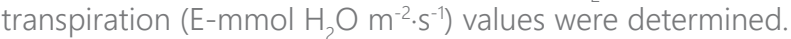
After these assessments, the shoots of the plants were collected and dried in a forced-air circulation $\left(60^{\circ} \mathrm{C}\right)$ until they reached a constant weight to determine the shoot dry weight of the aerial part (SDW).

Besides, one third (nine pots) of the treatments were disassembled, and the entire volume of material was homogenized, after which soil samples were collected. Then, the following biochemical attributes were analyzed: basal soil respiration (RBS) by capturing $\mathrm{CO}_{2}$ evolved by $\mathrm{NaOH}$ solution $(0.05 \mathrm{M})$, after 3 days of incubation according to Alef (1995); microbial biomass carbon (MBC) by the fumigation-extraction method described by Vance et al (1987); the $\mathrm{qCO}_{2}$ of each treatment was determined from the ratio between $\mathrm{BR}$ and $\mathrm{MBC}$, (Anderson and Domsch, 1993); the activity of the $\beta$-glucosidase enzyme according to the method of Eivazi and Tabatabai (1988) and the

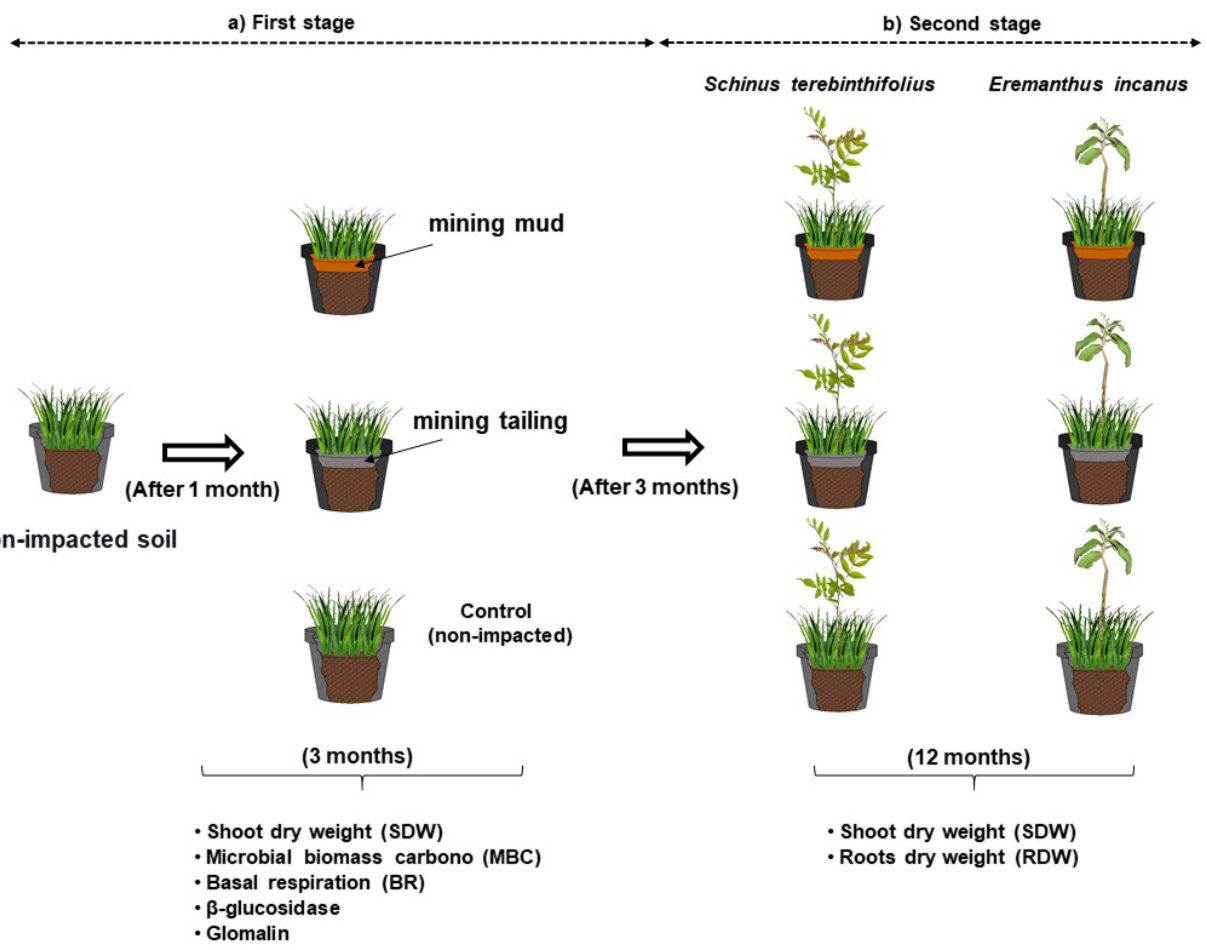

Fig. 1 Description of the experiment in a greenhouse to assess the impact of deposition of mud and tailings from iron mining on the soil biological and biochemical attributes and the establishment of Urochloa decumbens, Schinus terebinthifolius and Eremanthus incanus. 
extraction of easily extractable glomalin from the soil was carried out with sodium citrate solution according to the methodology described by Wright and Upadhyaya (1998) and its levels were quantified according to the method of described by Bradford (1976).

Second stage - Development of seedlings of tree species on impacted soils

In the second stage of the experiment, after cutting the shoots of $U$. decumbens, two tree species (Schinus terebinthifolius Raddi (Aroeirinha) and Eremanthus incanus (Less, ) (Candeia)) were planted in the remaining eighteen pots (Fig. 1). The seedlings of tree species were supplied by the UFLA seedling nursery. For one year the pots with the plants were kept in a greenhouse and irrigated to maintain field capacity. For this, the pots were weighed daily once a day and the volume of water needed to maintain the field capacity was added. After 12 months of cultivation, all plants were collected and their aerial parts and root systems were subjected to drying $\left(60^{\circ} \mathrm{C}\right)$ until reaching constant weight, to determine the shoot (SDW) and roots (RDW) dry weight.

\section{Statistical analysis}

The data were subjected to analysis of variance (ANOVA) and Tukey test at 5\% probability, using the SISVAR statistical program (Ferreira, 2014). Previous to normal and homoscedasticity were examined with the Shapiro-Wilk and Levene tests using software R (R Core Team, 2020), respectively, and were not violated.

\section{RESULTS}

Microbial biomass carbon (MBC) and basal respiration $(B R)$ and $q \mathrm{CO}_{2}$ were not affected $(p<0.05)$ by the deposition of mud or tailings. On the other hand, the activity of the $\beta$-glucosidase enzyme decreased $(p<0.05$ ) by $46 \%$ and $16 \%$ due to the deposition of mud and mining tailings, respectively. The Glomalin was also affected ( $p<$ 0.05 ) by the deposition of mud and mining tailings, in both cases leading to a reduction of about 19\% ( $p<0.05)$ in its contents when compared to the non-impacted soil, after three months of cultivation of $U$. decumbens (Tab. 3).

The SDW of $U$. decumbens was not significantly affected after three months of cultivation in soil impacted by mud or iron mining tailings (Tab. 4). A similar effect was observed for SDW and RDW of $E$. incanus, even after one year of cultivation on soils impacted by mud and tailings. On the other hand, the mud negatively affected the values of SDW and RDW of $S$. terebinthifolius, with a reduction of 21 and 24\%, respectively, when compared to the values observed in plants grown in non-impacted soil (Tab. 4).

Regarding gas exchange, there were no significant differences in rates and liquid photosynthesis (A), transpiration (E), and stomatal conductance (Gs) in plants of $U$. decumbens cultivated in non-impacted soil and soils impacted by mud or iron mining tailings (Tab. 5).

\section{DISCUSSION}

The high values for $\mathrm{MBC}$ indicate that the original soil microbiota was resistant to deposition of mud and mining tailings, keeping the statistically the same values to those observed for the non-impacted soil (Tab. 3). Although several studies have shown a reduction in microbial biomass in affected soils due to mining activities (Wang et al., 2007; Carneiro et al., 2008; Santos et al., 2013), it has also been reported that when adaptations of the remaining microbiota occur, in affected areas, it can maintain itself or even to re-colonize the soil, and so, it can raise $\mathrm{MBC}$ values (Carneiro et al., 2008; Santos et al., 2016), even if this increase in microbial biomass does not mean maintenance microbial diversity (Wang et al., 2007; Santos et al., 2016).

The BR rate also showed a balance between treatments, but the high values indicate intense microbiota activity (Tab. 3). High respiratory rate is related to consumption of organic compounds readily assimilated by soil microorganisms, directing microbial metabolism more to maintenance than to increasing microbial biomass, which commonly occurs in stressful conditions for soil microbiota (Carneiro et al., 2008; Santos et al., 2013; Silva et al., 2018). This aspect is relevant because the increase in $\mathrm{CO}_{2}$ emissions implies a reduction in the carbon stock of the soil over time.

The activity of $\beta$-glucosidase, an enzyme that is involved with carbon metabolism and obtaining energy by the microbial cell, was negatively affected by the deposition of the iron mining mud and tailings (Tab. 3). The lower activity this enzyme can be explained by the presence of excess metals such as manganese and iron itself, besides to others potentially toxic elements, which are commonly present in composition of the iron mining mud and tailings, as reported in this work (Tab. 1) and also verified by other authors (Segura et al., 2016; Santos et al., 2019). Another important aspect is the physical condition of both the mud and tailings, due to the high levels of silt (95\%) and sand (55\%) respectively (Tab. 1), also reported in other studies (Carmo et al., 2017; Batista et al, 2020), and that reduces the total porosity of the soil, especially the macropores, limiting the aeration of the soil and consequently the

Tab. 3 Biochemical attributes of soils, cultivated with Urochloa decumbens, impacted by the deposition of iron mining mud and tailings, and a non-impacted soil, in a greenhouse experiment.

\begin{tabular}{|c|c|c|c|c|c|}
\hline Treatments & $\begin{array}{c}\mathrm{MBC}^{\star} \\
\text { ( } \mu \mathrm{g} \mathrm{C} / \mathrm{g} \text { dry soil) }\end{array}$ & $\begin{array}{c}\mathrm{BR} \\
\left(\mathrm{mg} \mathrm{C}-\mathrm{CO}_{2} \mathrm{~g}^{-1} \cdot \mathrm{h}^{-1}\right)\end{array}$ & $\begin{array}{c}9 \mathrm{CO}_{2} \\
\left(\mathrm{~g} \mathrm{C}-\mathrm{CO}_{2} \mathrm{~g}^{-1} \mathrm{MBC} \mathrm{h}^{-1}\right)\end{array}$ & $\begin{array}{c}\beta-\text {-Glucosidase } \\
\left(\mu \mathrm{g} \text { PNP. } g^{-1} \text { dry soil } \cdot h^{-1}\right)\end{array}$ & $\begin{array}{l}\text { Glomalin } \\
\left(\mathrm{mg}^{-1} \mathrm{~g}^{-1}\right)\end{array}$ \\
\hline Mud & $633.28 a^{* *}$ & 18.79 a & $41.20 \mathrm{a}$ & $456.82 c$ & $2.88 \mathrm{~b}$ \\
\hline Tailing & 698.46 a & $20.96 a$ & 32.12 a & $712.46 b$ & $2.91 \mathrm{~b}$ \\
\hline Not-impacted soil & 790.02 a & $17.44 \mathrm{a}$ & $23.19 \mathrm{a}$ & $842.53 \mathrm{a}$ & $3.57 \mathrm{a}$ \\
\hline
\end{tabular}

*MBC - Microbial biomass carbon; BR - Basal respiration; $q \mathrm{CO}_{2}$ - Metabolic quotient. ** Means followed by the same letter in the column are not significantly different based on the Tukey test at $5 \%$ probability. 
Tab. 4 Shoot (SDW) and Root (RDW) dry weight of plants grown in soils impacted by deposition of iron mining mud and tailing, and in non-impacted control soil, in a greenhouse experiment Urochloa. decumbens was evaluated after three months of cultivation; Schinus terebinthifolius and Eremanthus incanus - evaluated after 12 months of cultivation.

\begin{tabular}{|c|c|c|c|c|c|}
\hline \multirow{3}{*}{ Treatments } & \multicolumn{3}{|c|}{ SDW } & \multicolumn{2}{|c|}{ RDW } \\
\hline & U. decumbens & S. terebinthifolius & E. incanus & S. terebinthifolius & E. incanus \\
\hline & \multicolumn{5}{|c|}{ 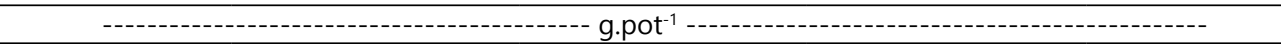 } \\
\hline Mud & $53.71 a^{*}$ & $4.04 \mathrm{~b}$ & $2.51 \mathrm{a}$ & $3.89 \mathrm{~b}$ & $2.24 \mathrm{a}$ \\
\hline Tailing & $53.20 \mathrm{a}$ & 5.47 a & $3.15 \mathrm{a}$ & $4.36 \mathrm{a}$ & $2.63 \mathrm{a}$ \\
\hline Not-impacted soil & $55.57 \mathrm{a}$ & $5.11 \mathrm{a}$ & $2.75 \mathrm{a}$ & $5.12 \mathrm{a}$ & $2.12 \mathrm{a}$ \\
\hline
\end{tabular}

Tab. 5 Photosynthesis (A), stomatal conductance (Gs), and transpiration (E) of Urochloa decumbens cultivated in soils impacted by deposition of iron mining mud and tailings, and in non-impacted soil, in a greenhouse experiment.

\begin{tabular}{cccc}
\hline \multirow{2}{*}{ Treatments } & $\mathrm{A}$ & $\mathrm{Gs}$ & $\mathrm{E}$ \\
\cline { 2 - 4 } & $\mathrm{\mu mol} \mathrm{CO}_{2} \mathrm{~m}^{-2} \mathrm{~s}^{-1} \mathrm{gs}$ & $-\mathrm{mol} \mathrm{H}_{2} \mathrm{O} \mathrm{m}_{-2} \mathrm{~s}^{-1}$ & $\mathrm{mmol} \mathrm{H}_{2} \mathrm{O} \mathrm{m}^{-2} \mathrm{~s}^{-1}$ \\
\hline Mud & $2.05 \mathrm{a}^{*}$ & $0.006 \mathrm{a}$ & $0.35 \mathrm{a}$ \\
Tailing & $2.53 \mathrm{a}$ & $0.003 \mathrm{a}$ & $0.30 \mathrm{a}$ \\
Not-impacted & $2.49 \mathrm{a}$ & $0.005 \mathrm{a}$ & $0.40 \mathrm{a}$ \\
\begin{tabular}{c} 
I soil \\
\hline
\end{tabular}
\end{tabular}

*Means followed by the same letter in the column are not significantly different $(P<0.05)$ based on the Tukey test

microbial activities performed by aerobic microorganisms (Pupin et al., 2009; Nawaz et al., 2013). Limitations in the enzymatic activities of the soil directly affect the cycling and the availability of carbon and nutrients for the plants and consequently can compromise the long-term restoration of impacted ecosystems (Batista et al., 2020).

The mining mud negatively affected glomalin concentrations (Tab. 3). This effect is related to the characteristic of the mud, which is a biologically inert material, and for this reason, it had a diluting effect on the glomalin concentrations due to its spillage on the natural soil used as substrate, compared to the not-impacted soil (Tab. 3).

A similar effect occurred with the tailings. However, unlike mud, tailings are a mixed material, since as a result of the rupture of the dam, the mud was originally revolved and, consequently, mixed with the natural soil along the bank of the Gualaxo do Norte River. Thus, the tailings changed the chemical and physical characteristics, as well as biological components of the natural soils of the places where it passed (Segura et al., 2016; Carmo et al., 2017; Prado et al., 2019; Santos et al., 2019). Thus, the tailings incorporated part of the chemical, physical and biological characteristics of the soil in the affected areas. Therefore, unlike mud, the tailings, collected on the banks of the Gualaxo do Norte river, one year after the accident, presented some microbial load and this must have contributed to the intermediate values to mud and not-impacted soil. Glomalin is a glycoprotein considered to be persistent in the soil ( 6 - 92 years) and takes part in the cementation of soil particles playing a key role in its aggregation (Wright and Upadhyaya, 1998, Rillig et al., 2001; Preger et al., 2007; Zhang et al., 2017). Therefore, this biological attribute plays a key role in improving the physical properties of the soil in areas impacted by mining, and for this reason, it can be an important indicator of the evolution of soil rehabilitation processes.

U. decumbens is known for being a very aggressive plant in terms of competition with other species, and the ability to grow in soils with low fertility and physical limitations (Flávio Neto et al., 2015; Monteiro et al., 2016; Silva et al., 2019). These characteristics explain the absence of significant differences in the plant's SDW in soil affected with mud and tailings from iron ore mining, compared with non-impacted treatment (Tab. 4). One of the characteristics that make the $U$. decumbens such competitive advantages possible in different environments is the high photosynthetic performance due to C4 metabolism. Plants with this metabolism need a lower concentration of $\mathrm{CO}_{2^{\prime}}$ are more efficient in the use of water and more effective in the production of biomass.

In the presence of mining tailings, the species S. terebinthifolius and E. incanus had SDW and RDW like those of cultivated plants in non-impacted soil by deposition of mining residues (Tab. 4). On the other hand, in the presence of iron mining mud only $E$. incanus was not affected. These results indicate that plant species respond differently to the type of material deposited. Mining mud and tailings have high $\mathrm{pH}$ values, which generally decreases the availability of potentially toxic elements for plants (table 1). However, even in these conditions, it is observed that the total and available levels of $\mathrm{Mn}$ in the mud was double those observed in the tailings (Tab. 1 and 2). In addition, total $\mathrm{Cr}$ and $\mathrm{Pb}$ contents were higher in the mud. Even high levels of silt in the mining mud favor the formation of a sealing layer, leading to limitations to root development. Combined effects of these characteristics for mining mud were more evident in affecting the development for $S$. terebinthifolius than for $U$. decunbens and $E$. incanus Therefore, depending on the area that will be rehabilitated, one species or another may be more suitable. However, both species can be considered in new stages of studies, including in the field, since the material deposited along the Gualaxo do Norte River, the main area physically affected by the collapse of the Fundão dam is predominantly of iron mining tailings, which is characterized by being a material more diluted (with natural soil) than the iron mining mud stored inside the dam.

\section{CONCLUSIONS}

Mud and tailings from iron mining did not affect the biological indicators: microbial biomass and basal respiration, nor the plant species $U$. decumbens and $E$. incanus. On the other hand, both conditions had negative effects on the activity of $\beta$-glucosidase, glomalin and development of $S$. terebinthifolius seedlings. Therefore, the recovery of areas impacted by iron mining residues 
must consider both improvements in the biological and biochemical activities of the soil, as well as the reintroduction of plant species more adapted to the new soil conditions.

\section{ACKNOWLEDGEMENTS}

We thank the Coordination for the Improvement of Higher Education Personnel (CAPES), the National Council for Scientific and Technological Development (CNPq), and the State of Minas Gerais Research Support Foundation (FAPEMIG-APQ-01661-16) for the financial support and scholarships granted to the authors.

\section{AUTHORSHIP CONTRIBUTION}

Project Idea: FAP, JVS, MACC

Funding: MACC

Database: MACC

Processing: ACRJ, AOS, ERB, FSN, FAP, JVS, MVB

Analysis: ACRJ, AOS, ERB, FSN, FAP, JVS, MVB, IFSA

Writing: ACRJ, AOS, ERB, FSN, FAP, JVS, MVB, IFSA MACC

Review: ACRJ, AOS, FAP, JVS, MVB, IFSA, MACC

\section{REFERENCES}

ACCIOLY, A. M. A : SIQUEIRA J. O. Contaminação química e biorremediação do solo. In: NOVAIS, R. F.: VENEGAS, V. H. A.: SCHAEFER, C. E. Tópicos em ciência do solo. SBCS, 2000. p. 299-352.

ALEF, K. Estimation of soil respiration (não encontrado na internet). In: ALEF K.; NANNIPIERI, P. Methods in applied soil microbiology and biochemistry Academic, 1995. p. 464-470.

ANDERSON, T. H.; DOMSCH, K. H. The metabolic quotient for $\mathrm{CO}_{2}\left(\mathrm{qCO}_{2}\right)$ as a specific activity parameter to assess the effects of environmental conditions, such $\mathrm{pH}$, on the microbial biomass of forest soil. Soil Biology Biochemistry, v. 25 , n. 3, p. 393-395, 1993

ARAÚJO, F. V.; SILVA, E. B.; SILVA, A. C.; BARBOSA, M. S.; NARDIS, B. O. PEREIRA, I. M. Initial Growth of Eremanthus incanus (Less.) Less in Soil with Manganese. Floresta e Ambiente, v. 25, n. 1, e20150226, 2018.

BARBOSA, M. V.: PEDROSO, D. F.; PINTO, F. A.; SANTOS, J. V.; CARNEIRO, M. A. C. Arbuscular mycorrhizal fungi and Urochloa brizantha: symbiosis and spore multiplication. Pesquisa Agropecuária Tropical, v. 49, e54530, 2019

BATISTA, E. R.; CARNEIRO, J. J.; PINTO, F. A.; SANTOS, J. V.; CARNEIRO, M. A C. Environmental drivers of shifts on microbial traits in sites disturbed by a large-scale tailing dam collapse. Science of The Total Environment, v. 738, p. 139453,2020

BRADFORD, M. M. A rapid and sensitive method for the quantitation of microgram quantities of protein utilizing the principle of protein-dye binding. Analytical Biochemistry, v. 72, n. 1-2, p. 248-254, 1976.

BOWLES, T. M.; ACOSTA-MARTÍNEZ, V.; CALDERÓN, F.; JACKSON, L. E. Soil enzyme activities, microbial communities, and carbon and nitrogen availability in organic agroecosystems across an intensively managed agricultural landscape. Soil Biology and Biochemistry, v. 68, p. 252-262, 2014.

CARNEIRO, M.A.C.; SIQUEIRA, J.O.; MOREIRA, F.M.S. SOARES A. L. .Carbono orgânico, nitrogênio total, biomassa e atividade microbiana do solo em duas cronossequências de reabilitação após a mineração de bauxita. Revista Brasileira de Ciência do Solo, v. 32, n. 2, p. 621-632, 2008.

CARMO F F : KAMINO, L H Y : TOBIAS JUNIOR, R : CAMPOS, I C : CARMO F. F.: SILVINO, G.; CASTRO, K. J. S. X: MAURO, M. L: RODRIGUES, $N$ U. A.; MIRANDA, M. P. S.; PINTO, C. E. F. Fundão tailings dam failures: the environment tragedy of the largest technological disaster of Brazilian mining in global context. Perspectives in ecology and conservation, v. 15, n. 3, p. 145-151, 2017.

COSTA, O. Y. A.: RAAIJMAKERS, J. M.; KURAMAE, E. E. Microbial extracellular polymeric substances: ecological function and impact on soil aggregation. Frontiers in microbiology, v. 9, 1636, 2018.
DAVILA, R. B.; FONTES, M. P. F.; PACHECO, A. A.; FERREIRA, M. S. Heavy metals in iron ore tailings and floodplain soils affected by the Samarco dam collapse in Brazil. Science of The Total Environment, v. 709, 136151, 2020.

DENG, J.; ORNER, E. P.; CHAU, J. F.; ANDERSON, E. M.; KADILAK, A. L.; RUBINSTEIN, R. L.; BOUCHILLON, G. M.; GOODWIN, R. A.; GAGE, D. J.; SHOR, L. M. Synergistic effects of soil microstructure and bacterial EPS on drying rate in emulated soil micromodels. Soil Biology and Biochemistry, v. 83, p. $116-124,2015$

DZIONEK, A.; WOJCIESZYŃSKA, D.; GUZIK, U. Natural carriers in bioremediation: a review. Electronic Journal of Biotechnology, v. 23, p. 2836,2016

EIVAZI, F.; TABATABAI, M. A. Glucosidases and galactosidases in soils. Soil Biology and Biochemistry, v. 20, n. 5, p. 601-606, 1988

FERREIRA, D. F. Sisvar: a Guide for its Bootstrap procedures in multiple comparisons. Ciência e Agrotecnologia, v. 38, n. 2, p. 109-112, 2014

FLÁVIO NETO 」. SEVERIANO E C: COSTA K A P. JUNNYOR W. S. G. GONÇALVES, W. G.; ANDRADE, R. Biological soil loosening by grasses from genus Brachiaria in crop-livestock integration. Acta Scientiarum. Agronomy, v. 37, n. 3, p. 375-383, 2015

FRANCHI, E.; ROLLI, E.; MARASCO, R.; AGAZZI, G.; BORIN, S.; COSMINA, P.; PEDRON, F.; ROSELLINI, I.; BARBAFIERI, M.; PETRUZZELLI, G. Phytoremediation of a multi contaminated soil: mercury and arsenic phytoextraction assisted by mobilizing agent and plant growth promoting bacteria. Journal of Soils and Sediments, v. 17, n. 5, p. $1224-1236,2017$.

GARCIA, L. C.; RIBEIRO, D. B.; ROQUE F. O.; OCHOA-QUINTERO, J. M.; LAURANCE, W. F. Brazil's worst mining disaster: Corporations must be compelled to pay the actual environmental costs. Ecological Applications, v. 27, n. 1, p. $5-9,2017$.

HATJE, V.; PEDREIRA, R. M. A.; REZENDE, C. E.; SCHETTINI, C. A. F.; SOUZA, G.C. MARIN, D. C.; HACKSPACHER, P.C. The environmental impacts of one of the largest tailing dam failures worldwide. Scientific reports, v. 7, n. 1, p. 1-13, 2017

HERZBERGER, A. J.; DUNCAN, D. S.; JACKSON, R. D. Bouncing back: plantassociated soil microbes respond rapidly to prairie establishment. Plos One, v. 9, n. 12, e115775, 2014

HOJATI, S.; NOURBAKHSH, F. Enzyme activities and microbial biomass carbon in a soil amended with organic and inorganic fertilizers. Journal of Agronomy, v. 5, n. 4, p. 563-569, 2006.

JACOBY, R.; PEUKERT, M.; SUCCURRO, A.; KOPRIVOVA, A.; KOPRIVA, S. The role of soil microorganisms in plant mineral nutrition-current knowledge and future directions. Frontiers in Plant Science, v. 8, p. 1617, 2017.

LEHMANN A: ZHENG, W: RILLIG M C Soil biota contributions to soil aggregation. Nature Ecology \& Evolution, v. 1, n. 12, p. 1828-1835, 2017.

LENART-BOROŃ, A.; BOROŃ, P. The effect of industrial heavy metal pollution on microbial abundance and diversity in soils - a review. In: Environmental risk Assessment of soil Contamination. p. 759-784, 2014.

MA, Y.; OLIVEIRA, R. S.; NAI, F.; RAJKUMAR, M.; LUO, Y.; ROCHA, I.; FREITAS, H. The hyperaccumulator Sedum plumbizincicola harbors metal-resistant endophytic bacteria that improve its phytoextraction capacity in multi-metal contaminated soil. Journal of Environmental Management, v. 156, p. 62-69, 2015.

MONTEIRO, L. C.; VERZIGNASSI, J. R., BARRIOS, S. C. L.; VALLE, C. B FERNANDES, C. D.; BENTEO, G. L.; LIBÓRIO, C. B. Brachiaria decumbens intraspecific hybrids: characterization and selection for seed production. Journal of Seed Science, v. 38, n. 1, p. 62-67, 2016.

MORGAN 」 B : CONNOLLY E L. Plant-soil interactions: nutrient uptake. Nature Education Knowledge, v. 4, n. 8, p. 2, 2013.

NAWAZ, M. F.; BOURRIE, G.; TROLARD, F. Soil compaction impact and modelling A review. Agronomy for Sustainable Development, v. 33, n. 2, p. 291-309, 2013.

PEDROSO, D. F.; · BARBOSA, M. V.; SANTOS, J. V.; PINTO, F. A.; SIQUEIRA J. O.; CARNEIRO, M. A. C. Arbuscular mycorrhizal fungi favor the initial growth of Acacia mangium, Sorghum bicolor, and Urochloa brizantha in soil contaminated with $\mathrm{Zn}, \mathrm{Cu} P \mathrm{~Pb}$ and $\mathrm{Cd}$. Bulletin of environmental contamination and toxicology, v. 101, n. 3, p. 386-391, 2018

PIRES, A. P. F.; REZENDE, C. L.; ASSAD, E.; LOYOLA, R.; SCARANO, F. R. Forest restoration can increase the Rio Doce watershed resilience. Perspectives in ecology and conservation, v. 15, n. 3, p. 187-193, 2017

PRADO, I. G. O.: SILVA, M. C. S. PRADO, D. G. O.: KEMMELMEIER, K.: PEDROSA B. G. SILVA, C. C. KASUYA, M. C. M. Revegetation process increases the diversity of total and arbuscular mycorrhizal fungi in areas affected by the Fundão dam failure in Mariana, Brazil. Applied Soil Ecology, v. 141, p. 84-95, 2019.

PREGER, A. C.; RILLIG, M. C.; JOHNS, A. R.; DU PREEZ, C. C.; LOBE, I. AMELUNG, W.; Losses of glomalin-related soil protein under prolonged arable cropping: a chronosequence study in sandy soils of the South African Highveld. Soil Biology and Biochemistry, v. 39, n. 2, p. 445-453, 2007.

PUPIN, B.; FREDDI, O. S.; NAHAS, E. Microbial alterations of the soil influenced by induced compaction. Revista Brasileira de Ciência do Solo, v. 33, n. 5, p. 1207-1213, 2009. 
RANGEL, W. M.; LONGATTI, S. M. O.; FERREIRA, P.; BONALDI, D. S.; GUIMARÃES, A. A: THIJS, S: WEYENS, N.: VANGRONSVELD, J: MOREIRA, F. Leguminosae native nodulating bacteria from a gold mine As-contaminated soil: Multi-resistance to trace elements, and possible role in plant growth and mineral nutrition. International journal of phytoremediation, v. 19, n. 10 p. $925-936,2017$.

R CORE TEAM. R: A Language and Environment for Statistical Computing. R Foundation for Statistical Computing. 2020. URL https://www.R-project.org/

RILLIG, M. C. Arbuscular mycorrhizae, glomalin, and soil aggregation. Canadian Journal of Soil Science, v. 84, n. 4, p. 355-363, 2004

RILLIG, M. C.; WRIGHT, S. F.; NICHOLS, K. A.; SCHMIDT, W. F.; TORN, M. S Large contribution of arbuscular mycorrhizal fungi to soil carbon pools in tropical forest soils. Plant Soil, 233, p. 167-177, 2001

SANTOS, J. V.; RANGEL, W. M.; GUIMARAEES, A. Z.; JARAMILLO, P. M. D RUFINI, M.: MARRA, L. M. M.: LOPEZ, M. V.: SILVA, M. A. P. SOARES, C. R. F. S.: MOREIRA, F. M. S. Soil biological attributes in arsenic-contaminated gold mining sites after revegetation. Ecotoxicology, v. 22, n. 10, p. 1526-1537, 2013

SANTOS, J. V.; VARÓN-LÓPEZ, M.; SOARES, C. R. F. S.; LEAL, P. L.; SIQUEIRA, O.; MOREIRA, F. M. S. Biological attributes of rehabilitated soils contaminated with heavy metals. Environmental Science and Pollution Research, v. 23, n. 7 p. $6735-6748,2016$

SANTOS, O: AVELLAR, F C : ALVES, M: TRINDADE, R C MENEZES, $M$. B FERREIRA, M. C.: FRANCA, G. S.; CORDEIRO, J.; SOBREIRA, F. G.; YOSHIDA I. M.; MOURA, P. M.; BAPTISTA, M. B.; SCOTTI, M. R. Understanding the Environmental Impact of a Mine Dam Rupture in Brazil: Prospects for Remediation. Journal of Environmental Quality, v. 48, n. 2, p. 439-449, 2019

SEGURA, F. R: NUNES, E. A. PANIZ, F. P. PAULELLI, A. C. C: RODRIGUES B: BRAGA, G. U. L.: PEDREIRA FILHO, W. R: BARBOSA JR. F: CERCHIARO G.; SILVA, F. F.; BATISTA, B. L. Potential risks of the residue from Samarco's mine dam burst (Bento Rodrigues, Brazil). Environmental Pollution, v. 218 p. 813-825, 2016.

SILVA, A. O.; COSTA, A. M.; TEIXEIRA, A. F. S.; GUIMARÃES, A. A.; SANTOS, J. V.; MOREIRA, F. M. S. Soil microbiological attributes indicate recovery of an iron mining area and of the biological quality of adjacent phytophysiognomies Ecological Indicators, v. 93, p. 142-151, 2018
SILVA, J. F. G.; GONÇALVES, W. G.; COSTA, K. A. P.; FLAVIO NETO, J.; BRITO, M. F. SILVA, F. C. SEVERIANO, E. C. Crop-livestock integration and the physical resilience of a degraded Latosol. Semina: Ciências Agrárias, v. 40, n. 6, p. 2973-2990, 2019.

SANTOYO, G.; MORENO-HAGELSIEB, G.; OROZCO-MOSQUEDA, M. C.; GLICK, B. R. Plant growth-promoting bacterial endophytes. Microbiological research, v. 183, p. 92-99, 2016

STUMPF, L.: PAULETTO, E. A.: CASTRO, R. C.:PINTO, L. F. S.; FERNANDES, F. F. SILVA, T, S: AMBUS, J. V. GARCIA G. F.; LIMA, C L. R.; NUNES, M. R. Capability of grass in recovery of a degraded area after coal mining. Agrociencia, vol. 48, n.5, p. 477- 487, 2014.

TAK, H. I.; AHMAD, F.; BABALOLA, O. O. Advances in the application of plant growth-promoting rhizobacteria in phytoremediation of heavy metals. Reviews of Environmental Contamination and Toxicology, v. 223. p. 33-52, 2013

VANCE, E. D.; BROOKES, P. C.; JENKINSON, D. S. An extraction method for measuring soil microbial biomass $C$. Soil Biology and Biochemistry, v. 19, n. 6, p. 703-707, 1987

VAN DER HEIJDEN, M. G. A.; BARDGETT, R. D.; VAN STRAALEN, N. M. The unseen majority: soil microbes as drivers of plant diversity and productivity in terrestrial ecosystems. Ecology letters, v. 11, n. 3, p. 296-310, 2008.

WANG, $Y$ : SHI, J: WANG, $H$ : LIN, $\mathrm{Q}$ : CHEN $X$ : CHEN $Y$ The influence of soil heavy metals pollution on soil microbial biomass, enzyme activity, and community composition near a copper smelter. Ecotoxicology and environmental safety, v. 67, n. 1, p. 75-81, 2007

WRIGHT, S. F.; UPADHYAYA, A. A survey of soils for aggregate stability and glomalin, a glycoprotein produced by hyphae of arbuscular mycorrhizal fungi. Plant and soil, v. 198, p. 97-107, 1998.

ZAGO, V. C. P.; DORES, N. C.; WATTS, B. A. Strategy for phytomanagement in an area affected by iron ore dam rupture: A study case in Minas Gerais State, Brazil. Environmental pollution, v. 249, p. 1029-1037, 2019

ZHANG, J.; TANG, X.; ZHONG, S.; YIN, G.; GAO, Y.; HE, X. Recalcitrant carbon components in glomalin-related soil protein facilitate soil organic carbon preservation in tropical forests. Scientific reports, v. 7, p. 2391, 2017. 